\title{
Effect of post-emergence herbicides on stress indicators in quinoa
}

\author{
Jorge Merino ${ }^{1,3}$, Alberto Pedreros ${ }^{2 *}$, Susana Fischer $^{2}$, and María D. López ${ }^{2}$ \\ 'Instituto Nacional de Investigaciones Agropecuarias (INIAP), Estación Experimental Santa Catalina, Panamericana Sur km 1 vía \\ Tambillo, Cantón Mejía, Pichincha, Ecuador. \\ ${ }^{2}$ Universidad de Concepción, Facultad de Agronomía, Av. Vicente Méndez 595, Chillán, Chile. \\ "Corresponding author (jpedrerosl@udec.cl). \\ ${ }^{3}$ Universidad de Concepción, Facultad de Agronomía, Programa de Doctorado en Ciencias de la Agronomía, Av. Vicente Méndez 595, \\ Chillán, Chile.
}

Received: 6 June 2019; Accepted: 29 September 2019; doi:10.4067/S0718-58392020000100021

\begin{abstract}
The impact of herbicide application on the accumulation of secondary metabolites and photosynthesis as stress indicators in the quinoa (Chenopodium quinoa Willd.) crop is unknown. The objective of the present study was to evaluate the effect of two post-emergence herbicides on production, total polyphenol content, and chlorophyll fluorescence in quinoa. The experiments were conducted for two consecutive seasons using a completely randomized block design with seven treatments, including two herbicides and three commercial product rates, as well as a control without herbicide application. Production parameters, yield components, and stress indicators were evaluated. Yield was affected $(P<$ 0.05 ) by herbicide application in some treatments; control and treatment with only one bentazon application varied from 1851.23 to $1235.03 \mathrm{~kg} \mathrm{ha}^{-1}$, respectively. Yield affected the number of grains per plant $(P<0.05)$; control and treatment with only one bentazon application decreased yield from 3984.60 to $2040.94 \mathrm{~kg} \mathrm{ha}^{-1}$, respectively. Total polyphenol content and percentage of germination in quinoa grains were not affected by stress caused by herbicide application $(P>$ 0.05). The herbicide fomesafen did not affect the maximum quantum yield, while the herbicide bentazon had a significant effect $(P<0.05)$ during the application. Three sequential applications of bentazon and fomesafen in the absence of weeds were sufficient to achieve a yield that was equal $(P>0.05)$ to the control.
\end{abstract}

Key words: Chemical weed control in quinoa, Chenopodium quinoa, chlorophyll fluorescence, stress indicators, total polyphenols.

\section{INTRODUCTION}

Quinoa (Chenopodium quinoa Willd.) has been cultivated in the cool and semiarid regions of various South American countries because of its nutritional properties, including high concentrations of proteins, essential amino acids, unsaturated fat acids, vitamins, minerals, and other beneficial compounds (Bazile et al., 2016). It has recently attracted a great deal of attention (Navruz-Varli and Sanlier, 2016). Quinoa has high genetic variability that allows growth and adaptation to adverse environmental conditions due to its great abiotic stress resistance (Abderrahim et al., 2015; Navruz-Varli and Sanlier, 2016; Li and Zhu, 2018). Due to current inefficient results obtained with herbicides in the quinoa crop, weed control is manual or mechanical; however, some options are being studied for herbicide application at pre-emergence (metamitron and propyzamide) and post-emergence (propyzamide), which have been tolerated by quinoa. Some sulfonylurea-type herbicides have also been tested at post-emergence and have demonstrated selectivity in quinoa; however, further evaluation is necessary to draw sound conclusions (Díaz et al., 2015). Herbicides applied at post-emergence cause stress in crops by negatively influencing photosynthesis, the opening and closing of stomata, 
and increasing susceptibility to attack by fungi, and/or altering physiological and metabolic functions (Das and Mondal, 2014). Thus, plant metabolism is altered by herbicide application and produces changes in fluorescence emission that are detected in leaves before any other visible effect (Barbagallo et al., 2003). Chlorophyll fluorescence has also proven to be a basic non-invasive technique to study and quantify damage to the photosynthetic apparatus in leaves as a response to stress caused by abiotic factors (Baker and Rosenqvist, 2004). Chlorophyll fluorescence is affected by herbicides that depend on light, such as inhibitors of glutamine synthetase, protoporphyrinogen oxidase, and carotenoid biosynthesis; they also affect the stability of the photosynthetic apparatus and can indirectly alter chlorophyll fluorescence (Hess, 2000). The $\mathrm{F}_{\mathrm{v}} / \mathrm{F}_{\mathrm{m}}$ parameter is an important component to measure chlorophyll fluorescence and evaluate herbicide toxicity in plants. The $F_{\sqrt{ }} / \mathrm{F}_{\mathrm{m}}$ measures the maximum quantum efficiency of the PSII photochemical activity while the PSII reaction centers are open (Baker and Rosenqvst, 2004). Reduced crop growth, especially decreased yield, can be influenced by a decrease in photosynthesis (Ali and Honermeier, 2016); however, this stress on the crops alters the quantity of secondary plant metabolites and affects yield (Olivoto et al., 2016). Plant stress also reduces biomass production, but it increases the polyphenol concentration in tissues (De Abreu and Mazzafera, 2005).

Chemical methods to control weeds in the quinoa crop are therefore important factors that can directly affect yield; the effect on total polyphenol content in the grain and chlorophyll fluorescence as stress indicators is still unknown. Therefore, the objective of the present study was to evaluate the effect of two post-emergence herbicides on production, total polyphenol content, and chlorophyll fluorescence in quinoa.

\section{MATERIALS AND METODOS}

\section{Plant material and experimental design}

The experiments were conducted for two consecutive seasons at El Nogal Experimental Station $\left(36^{\circ} 34^{\prime}\right.$ S, $74^{\circ} 06^{\prime}$ W) in the Nuble Region, Chile. A randomized complete block experimental design was used with four replicates. The experimental unit was $4 \times 2 \mathrm{~m}$ and consisted of four rows of quinoa (Chenopodium quinoa Willd.) 'Regalona' plants with $0.5 \mathrm{~m}$ spacing. Seven treatments were established in each replicate, the herbicides fomesafen (5-[2-chloro-4-(trifluoromethyl) phenoxy]- $N$-methylsulfonyl-2-nitrobenzamide; $250 \mathrm{~g} \mathrm{~L}^{-1} \mathrm{SL}$, Flex, Syngenta, Sao Paulo, Brazil) and bentazon (2,2-dioxo3-propan-2-yl-1H-2lambda6,1,3-benzothiadiazin-4-one; $480 \mathrm{~g} \mathrm{~L}^{-1} \mathrm{SL}$, Basagran, BASF, Ludwigshafen, Germany) were applied, and the commercial product rate was split in 1,2, and 3 sequential applications (Table 1). Fom1 and Bent1 were the fomesafen and bentazon rates sprayed once together. Similarly, Fom2 and Bent2 were the rates split into two applications with a half dose of each one sprayed every 9 d, respectively, while the Fom 3 and Bent 3 rates were split into three applications with one third sprayed every $9 \mathrm{~d}$. The treatment without herbicide (TWH) was the treatment with manual weed control.

\section{Agronomic management}

The soil was prepared in each season using one pass with a moldboard plow, two passes with a disc harrow plow, and two passes with a vibro-cultivator. Continuous manual sowing occurred in mid-October at a $12 \mathrm{~kg} \mathrm{ha}^{-1}$ seeding rate and $0.5 \mathrm{~m}$

Table 1. Description of treatments in the 2015-2016 and 2016-2017 seasons.

\begin{tabular}{lccccc}
\hline Treatments & $\begin{array}{c}\text { Active } \\
\text { ingredient (ai) }\end{array}$ & Rate ai & $\begin{array}{c}\text { Commercial } \\
\text { product (cp) }\end{array}$ & Rate cp & Application frequency \\
\hline TWH & Control & L ha $^{-1}$ & & L ha $^{-1}$ & \\
Fom3 & Fomesafen & 83 & Flex & 0.33 & Without herbicide \\
Fom2 & Fomesafen & 125 & Flex & 0.50 & 2 applications, once every 9 d \\
Fom1 & Fomesafen & 250 & Flex & 1.00 & Single application \\
Bent3 & Bentazon & 317 & Basagran & 0.66 & 3 applications, once every 9 d \\
Bent2 & Bentazon & 480 & Basagran & 1.00 & 2 applications, once every 9 d \\
Bent1 & Bentazon & 960 & Basagran & 2.00 & Single application \\
\hline
\end{tabular}

ai: Active ingredient; $\mathrm{cp}$ : commercial product; TWH: treatment without herbicide application; Fom1 and Bent1: full rate sprayed once; Fom 2 and Bent2: split rate in two applications every 9 d; Fom 3 and Bent3: split rate in three applications every $9 \mathrm{~d}$. 
row spacing. After soil analysis, fertilization was uniformly applied as $100 \mathrm{~kg} \mathrm{P}_{2} \mathrm{O}_{5}$ ha $^{-1}$ and $50 \mathrm{~kg} \mathrm{~K}_{2} \mathrm{O} \mathrm{ha}^{-1}$ before sowing together with $160 \mathrm{~kg} \mathrm{~N}^{-1}$ of which $50 \%$ was applied at the four-true-leaf stage and 50\% at the beginning of branching. Furrow irrigation was used to facilitate homogeneous water flow; mechanical/manual weed removal was carried out three times with a hand hoe in all treatments, including TWH.

\section{Agronomic variables and yield components}

The population was standardized at the beginning of the experiments to 18 plants $\mathrm{m}^{-1}$ and measurements were taken in $2 \mathrm{~m}$ of the two central rows of each plot. Population and crop growth were evaluated at 7,30, and $60 \mathrm{~d}$ after the first application (DFA). Each population and growth evaluation was associated with the crop phenological stages proposed by Mujica and Canahua (1989). Plant height was determined by averaging the seven first plants of the selected section. Likewise, yield per unit area $\left(\mathrm{kg} \mathrm{ha}^{-1}\right)$, number of grains per plant, and 1000-grain weight $(\mathrm{g})$ were determined. The methodology proposed by Carciochi et al. (2014), with some modifications, was used to evaluate seed germination.

\section{Stress indicators: chlorophyll fluorescence and total polyphenols}

The maximum quantum yield $\left(\mathrm{F}_{v} / \mathrm{F}_{\mathrm{m}}\right)$ was measured as a chlorophyll fluorescence parameter. The methodology proposed by Mehta et al. (2010), with some modifications, was used to measure $F_{v} / F_{m}$ on the surface of the quinoa leaves with a leaf clip and OS5p+ fluorometer (Opti-sciences, Hudson, New Hampshire, USA). One plant from each plot was marked and $\mathrm{F}_{\mathrm{v}} / \mathrm{F}_{\mathrm{m}}$ was measured for three consecutive days after herbicide application. Samples were adapted to darkness for $30 \mathrm{~min}$ before taking the measurements at ambient temperature.

To determine total polyphenols in quinoa seeds, $20 \mathrm{~g}$ quinoa seed samples from each treatment were ground with a mill (1093, Cyclotec, Barcelona, Spain). Extract preparation was carried out according to the method described by Fischer et al. (2013) with some modifications. The supernatant was filtered, placed in amber glass jars, and stored at $4{ }^{\circ} \mathrm{C}$ until analysis. Total polyphenols were determined by the Folin-Ciocalteu method described by Miranda et al. (2010) with some modifications. Results were expressed as mg gallic acid equivalents (GAE) $\mathrm{g}^{-1}$ and all measurements were in triplicate. Two samples with the two herbicides at $100 \%$ commercial rate were included to verify the possible reaction of the herbicides on the Folin-Ciocalteu reagent and rule out false positives.

\section{Statistical analysis}

Data were subjected to ANOVA at $P<0.05$ after verifying the assumptions of normal distribution and homogeneity of variances. When these assumptions were not fulfilled, transformations were performed with the $\ln (x+1)$ function. Means were compared by the LSD test at the $95 \%$ confidence level. The statistical analysis was performed with the INFOSTAT statistical program (Di Rienzo et al., 2017).

\section{RESULTS AND DISCUSSION}

To compare the results of the variables between the first and second season, a combined analysis of the experiments was performed in which the interaction between year and treatment for all the variables was nonsignificant $(P>0.05)$; data were therefore grouped and analyzed together.

\section{Agronomic variables and yield components}

Precipitation in the 2015-2016 and 2016-2017 seasons (October to February) was 113.30 and $124.60 \mathrm{~mm} \mathrm{mo}^{-1}$, respectively; precipitation in October of each season was 98.60 and $65.00 \mathrm{~mm} \mathrm{mo}^{-1}$, respectively. The crop faced environmental conditions of high precipitation and a gradual temperature increase in the early stages, which caused higher weed density; plots were weeded three times during the experiment, which allowed evaluating the direct effect of the herbicides on the crop.

The quinoa population was constant $(P>0.05)$ in all the treatments, whereas plant height varied $(P<0.05)$ with the treatments (Table 2). Plant height was not different between treatments up to 7 DFA $(P>0.05)$; however, treatments with bentazon at 30 DFA exhibited the highest plant height, which was equal to the TWH $(P>0.05)$ but higher $(P<$ $0.05)$ than the treatment with fomesafen in two sequential applications. Finally, at 60 DFA, treatments with bentazon exhibited the same plant height $(P>0.05)$ as the TWH and higher $(P<0.05)$ than the three treatments with fomesafen. 
Table 2. Plant height response to the application of two post-emergence herbicides (fomesafen and bentazon) at different number of days after first application (DFA) in the 'Regalona' quinoa crop.

\begin{tabular}{lclll}
\hline Treatments & 0 DFA & 7 DFA & 30 DFA & 60 DFA \\
\hline TWH & $14.0 \mathrm{a}$ & $42.0 \mathrm{a}$ & $80.7 \mathrm{abc}$ & $86.1 \mathrm{a}$ \\
Fom3 & $13.7 \mathrm{a}$ & $41.6 \mathrm{a}$ & $77.2 \mathrm{bc}$ & $79.1 \mathrm{bc}$ \\
Fom2 & $14.2 \mathrm{a}$ & $41.7 \mathrm{a}$ & $74.6 \mathrm{c}$ & $75.0 \mathrm{c}$ \\
Fom1 & $14.5 \mathrm{a}$ & $41.6 \mathrm{a}$ & $78.9 \mathrm{bc}$ & $80.6 \mathrm{~b}$ \\
Bent3 & $14.2 \mathrm{a}$ & $41.3 \mathrm{a}$ & $83.0 \mathrm{ab}$ & $85.5 \mathrm{a}$ \\
Bent2 & $13.8 \mathrm{a}$ & $43.0 \mathrm{a}$ & $86.9 \mathrm{a}$ & $88.0 \mathrm{a}$ \\
Bent1 & $13.8 \mathrm{a}$ & $41.6 \mathrm{a}$ & $83.4 \mathrm{ab}$ & $86.7 \mathrm{a}$ \\
\hline
\end{tabular}

Different lowercase letters indicate significant differences between treatments according to LSD test $(P \leq 0.05)$.

TWH: Treatment without herbicide application; Fom1 and Bent1: full rate sprayed once; Fom2 and Bent2: split rate in two applications every 9 d; Fom3 and Bent3: split rate in three applications every $9 \mathrm{~d}$.

Two applications of fomesafen resulted in quinoa plants with lower height $(75 \mathrm{~cm})$ and were equal $(P>0.05)$ only to the same herbicide with three sequential applications.

Crop yield (Table 3$)$ was affected $(P<0.05)$ by herbicide application in the absence of weeds. The highest value was obtained in the TWH and the bentazon and fomesafen treatments, both with three sequential applications and values of $1851.23,1772.55$, and $1698.78 \mathrm{~kg} \mathrm{ha}^{-1}$, respectively, and these values were statistically equal. The lowest yield occurred in the treatments with both herbicides and for two sequential applications and a single application; values were 1431.90 and $1427.37 \mathrm{~kg} \mathrm{ha}^{-1}$ for fomesafen and 1439.98 and $1235.03 \mathrm{~kg} \mathrm{ha}^{-1}$ for bentazon, respectively, and these values were statistically equal.

The highest yields were obtained in the TWH and in the bentazon and fomesafen treatments with three sequential applications. The fomesafen and bentazon rates split twice or together decreased yield when compared with TWH and Fom 3 and Bent3. It is possible that herbicide treatments with one third of the commercial rate applied sequentially once every $9 \mathrm{~d}$ (Fom 3 and Bent3) allowed the crop to detoxify the partial herbicide rates and prevented the yield from being affected. In contrast, treatments at half or full rate sprayed twice or once, respectively, could have affected quinoa growth and development, leading to lower yield.

In a similar study of bean, Pedreros and Tay (2003) used fomesafen and bentazon sequential applications and determined that dry grain yield increased when herbicides were fractionated in three applications rather than a single application. This is because herbicides were applied in plots with weeds; therefore, when the herbicides controlled weeds, interspecific competition decreased and the crop was able to express its potential. In contrast, herbicides in the present study were applied in manually weeded quinoa plots to evaluate the direct effect of the herbicide on the crop. In a study of chemical weed control in quinoa, Molina et al. (2014) used three post-emergence herbicides: fomesafen, bentazon, and metsulfuron-methyl, as well as two controls (manual weed control and no weed control). They obtained the highest yield in manual weed control, which was no different from the three fomesafen applications, whereas the lowest yield was obtained with a single application of metsulfuron-methyl.

Table 3. Yield, number of grains per plant, 1000-grain weight, percentage of germination, and total polyphenol response to the application of two post-emergence herbicides in the 'Regalona' quinoa crop.

\begin{tabular}{lccccc}
\hline Treatments & Yield & $\begin{array}{c}\text { Number of grains } \\
\text { per plant }\end{array}$ & $\begin{array}{c}\text { 1000-grain } \\
\text { weight }\end{array}$ & Germination & $\begin{array}{c}\text { Total } \\
\text { polyphenols }\end{array}$ \\
\hline TWH & $\mathrm{kg} \mathrm{ha}^{-1}$ & & $\mathrm{~g}$ & $\%$ & $\mathrm{mg} \mathrm{GAE} \mathrm{g-1}^{-1}$ \\
Fom3 & $1851.2 \mathrm{a}$ & $3984.6 \mathrm{a}$ & $2.8 \mathrm{a}$ & $94.4 \mathrm{a}$ & $2.9 \mathrm{a}$ \\
Fom2 & $1698.8 \mathrm{a}$ & $3388.8 \mathrm{~b}$ & $2.8 \mathrm{a}$ & $93.3 \mathrm{a}$ & $2.9 \mathrm{a}$ \\
Fom1 & $1431.9 \mathrm{~b}$ & $2545.8 \mathrm{c}$ & $2.9 \mathrm{a}$ & $93.6 \mathrm{a}$ & $2.9 \mathrm{a}$ \\
Bent3 & $1427.4 \mathrm{~b}$ & $2544.5 \mathrm{c}$ & $2.8 \mathrm{a}$ & $92.6 \mathrm{a}$ & $2.9 \mathrm{a}$ \\
Bent2 & $1772.6 \mathrm{a}$ & $3678.9 \mathrm{~b}$ & $2.9 \mathrm{a}$ & $94.6 \mathrm{a}$ & $3.0 \mathrm{a}$ \\
Bent1 & $1440.0 \mathrm{~b}$ & $2679.4 \mathrm{c}$ & $2.9 \mathrm{a}$ & $93.5 \mathrm{a}$ & $3.0 \mathrm{a}$ \\
\hline
\end{tabular}

Different lowercase letters indicate significant differences between treatments according to LSD test $(P \leq 0.05)$. TWH: Treatment without herbicide application; Fom 1 and Bent1: full rate sprayed once; Fom2 and Bent2: split rate in two applications every $9 \mathrm{~d}$; Fom 3 and Bent3: split rate in three applications every $9 \mathrm{~d}$. 
Similar studies conducted in other crops have demonstrated reduced yield components because of herbicide application. Ali and Honermeier (2016) evaluated the influence of post-emergence herbicides on artichoke yield with treatments that included five herbicides applied after germination. When these were compared with mechanical weeding, the herbicide pyridate (phenyl-pyridazine) was the one that most affected yield in the two harvests of the first production cycle and the second harvest of the second production cycle compared with the TWH. Karimmojeni et al. (2013) suggested that bentazon was a good option to control chemically broadleaf weeds in flaxseed because it did not reduce yield and produced acceptable phytotoxicity in the crop.

Table 3 shows that the variable number of grains per plant was affected by herbicide application $(P<0.05)$; the TWH exhibits the highest value, 3984.60 grains plant ${ }^{-1}$, which is significantly different from the rest of treatments. Meanwhile, the lowest value, 2040.94 grains plant $^{-1}$, is exhibited in the treatment with a single bentazon application. This would indicate that stress produced in the plant by a single bentazon application during the early physiological stages of the quinoa crop directly affected this variable and therefore yield. The TWH treatment had the highest number of grains per plant and was higher than all the other treatments. This variable was related directly to plant yield, which was higher in this treatment (data not shown). This can be due to the fact that when there is no competition with weeds or applied herbicides, photoassimilates are used in the growth and storage processes and form the optimal number of grains they can fill (Merino et al., 2019). There is also a direct influence of factors such as irradiance levels, water potential, nutrients, and duration of the formation of potential harvest organs on the number of these organs. Moreover, not all organs begin effective filling and those that do are established in a period going from anthesis to the beginning of the effective growth of the harvest organ (Hall, 1980). It is possible that the reactive oxygen species (ROS) generated by quinoa plants exposed to early bentazon application at an initial physiological stage impeded adequate herbicide metabolism, and ROS that were not metabolized and interfered at some stage of quinoa grain formation to form only the number of grains that they would be able to fill.

The 1000-grain weight variable was constant $(P>0.05)$ in all treatments (Table 3$)$ with values ranging between 2.83 and $2.89 \mathrm{~g}$, which would indicate that herbicide application did not affect this variable that was the most stable. Mellado and Pedreros (2005) evaluated the effect of four herbicides on yield and quality of wheat grain during grain maturity and concluded that from the semi-hard grain stage onwards any of the herbicides used in those experiments can be applied without affecting the 1000-grain weight variable. This is because from the semi-hard grain stage onwards, the wheat grain condition is a semi-hard mass that is physiologically mature and has completed the transport of nutrients from leaves, stems, and spikes to the grain. Therefore, the maturity stage impedes the displacement of the applied systemic herbicides.

Height, yield, and number of grains per plant were affected in the present study when two herbicides were applied in the absence of weeds; we also demonstrated that the measurement of agronomic variables after herbicide application treatments has been a procedure used to characterize different herbicides (Pavlovic et al., 2008). In addition, herbicide application frequency was an important factor that influenced the variables; therefore, treatments with three sequential applications exhibited better crop response and allowed quinoa to detoxify effectively the herbicides. Thus, detoxification based on the metabolism of toxic compounds in plants aims to reduce the compound's toxic capacity, isolate or expel it, and prevent the damage it can cause. Bentazon and fomesafen belong to the group of photosynthesis inhibitor and photosynthetic pigment inhibitor herbicides, respectively; plants exposed to these herbicides produce ROS, but mainly cause an excess of active forms of $\mathrm{O}_{2}$, which generate lipid destruction by forming lipid radicals in polyunsaturated fatty acids (Hess, 2000; Lascano et al., 2003). Lipid peroxidation increases with herbicide stress and is correlated with the damage to the lipid membrane and amount of stress (Ekmekci and Terzioglu, 2005; Lukatkin et al., 2013). To eliminate these ROS, plants activate compounds in their tissues that act as antioxidant defense systems, such as ascorbic acid, and enzymes that interact with ROS, such as catalase, ascorbate peroxidase, and peroxidase (Blokhina et al., 2003; Lascano et al., 2003; Lukatkin et al., 2013). Pitty (2018) mentions that the metabolism in herbicides can be caused by an acceleration of the herbicide metabolism that forms nonphytotoxic compounds, decreases absorption or translocation, or places the herbicide in organelles in which it does not damage the plant. Pavlovic et al. (2008) evaluated the morphophysiological traits and sensitivity to atrazine in Chenopodium album L. and point out that the herbicide metabolism is usually an inherited quantitative characteristic. They concluded that the metabolism of the PSII inhibitor herbicides could have contributed to atrazine tolerance of a C. album biotype.

Finally, the evaluated percentage of germination showed that herbicide application did not affect germination and was constant $(P>0.05)$ in all treatments (Table 3$)$ with values ranging between 95\% and 93\%. In a similar study, Rinella et 
al. (2010) applied three herbicides (2,4-D, dicamba, and picloram) to Bromus japonicus Houtt.; they observed a negative effect on seed germination when the herbicides were applied during the entire plant cycle and concluded that the final reproductive stages can often be more sensitive to herbicide application than other growth stages.

\section{Stress indicators: chlorophyll fluorescence and total polyphenols}

The amount of total polyphenols was not affected by herbicide application and was constant $(P>0.05)$ in all treatments with values ranging from 2.85 to $3.06 \mathrm{mg} \mathrm{GAE} \mathrm{g}^{-1}$; the two herbicides, fomesafen and bentazon at the full commercial product herbicide rate, ddi not react with the procedure and exhibited a value of $0 \mathrm{mg} \mathrm{GAE} \mathrm{g}^{-1}$ (Table 3). Polyphenols are secondary metabolites important in plants because they perform functions in response to stress conditions (Miranda et al., 2013). In the present study, although stress caused by bentazon and fomesafen affected yield, it was not sufficient to alter the total polyphenol concentration. Ali and Honermeier (2016) applied five post-emergence herbicides in artichoke and observed that all the treatments increased caffeoylquinic acid content in leaves compared with the TWH during the first growth stage of the first period. No significant differences were detected in the second growth stage. As for flavonoids, they found that no herbicide affected their accumulation; finally, the TWH produced the lowest quantity of polyphenols (caffeoylquinic acid and flavonoids) during the two growth stages.

The maximum quantum yield related to fluorescence was not affected by fomesafen application (Figure 1) at any commercial rate and all treatments exhibited similar $\mathrm{F}_{\mathrm{v}} / \mathrm{F}_{\mathrm{m}}$ values $(P>0.05)$. Therefore, fomesafen did not affect the photosynthetic apparatus of the quinoa plants.

The bentazon application revealed changes $(P<0.05)$ in the maximum quantum yield values (Figure 2$)$. On the day after the first application (Figure 2A), all treatments exhibited similar $\mathrm{F}_{\sqrt{ }} / \mathrm{F}_{\mathrm{m}}$ values $(P>0.05)$. On the second day after the first application, treatments with two and a single bentazon application showed variations in the $\mathrm{F}_{\mathrm{v}} / \mathrm{F}_{\mathrm{m}}$ values. The single bentazon application $F_{v} / F_{m}$ value (0.61) significantly decreased compared with the TWH. The bentazon treatment with two applications exhibited a variation in $\mathrm{F}_{\mathrm{v}} / \mathrm{F}_{\mathrm{m}}$ with a value of 0.75 , while the TWH and treatment with three bentazon applications maintained values near 0.80. Finally, on the third day after the first application, the bentazon treatment with a single application managed to recover a little by increasing its $\mathrm{F}_{\mathrm{v}} / \mathrm{F}_{\mathrm{m}}$ value to 0.65 . However, the bentazon treatment with two applications had an $F_{v} / F_{m}$ value of 0.74 , which was lower than the TWH, whereas the TWH and the bentazon treatment with three applications maintained a value near 0.80. On the day after the second application (Figure $2 \mathrm{~B}$ ), the $\mathrm{F}_{v} / \mathrm{F}_{\mathrm{m}}$ values of the bentazon treatments with three and two applications were different $(P<0.05)$ and lower than the TWH, while the bentazon treatment with a single application maintained values near 0.80 . However, the highest stress occurred in the bentazon treatment with three applications since it exhibited an $\mathrm{F}_{\mathrm{v}} / \mathrm{F}_{\mathrm{m}}$ value of 0.65 . On the second day after the second application, the TWH and bentazon treatment with a single application maintained values near 0.80 , whereas $\mathrm{F}_{\mathrm{v}} / \mathrm{F}_{\mathrm{m}}$ values

Figure 1. Response of maximum quantum yield to post-emergence herbicide application of fomesafen in the 'Regalona' quinoa crop in the first $(\mathrm{A})$, second $(\mathrm{B})$, and third (C) applications.

A

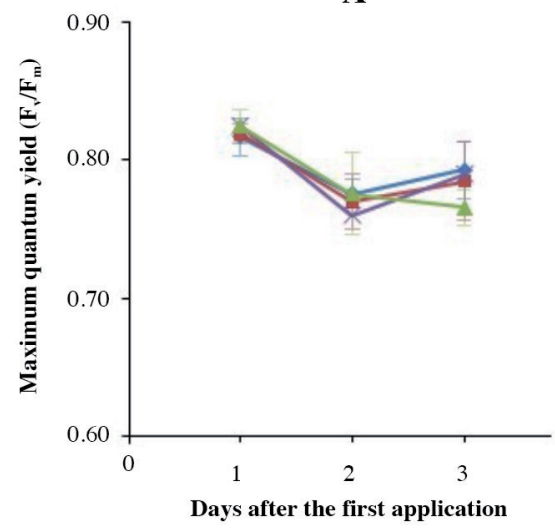

B
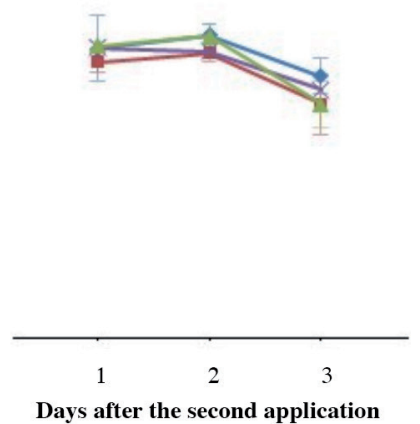

C
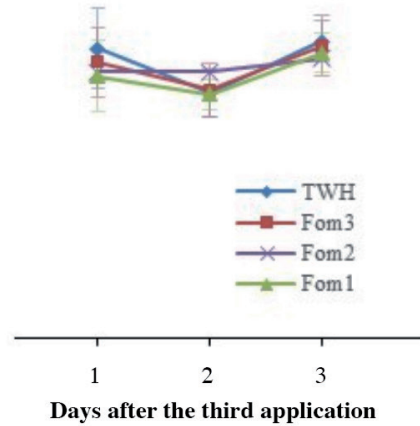

Bars represent the standard deviation of the mean in each treatment.

TWH: Treatment without herbicide application; Fom 1 and Bent1: full rate sprayed once; Fom 2 and Bent2: split rate in two applications every

$9 \mathrm{~d}$; Fom 3 and Bent3: split rate in three applications every $9 \mathrm{~d}$. 
Figure 2. Response of maximum quantum yield to post-emergence herbicide application of bentazon in the 'Regalona' quinoa crop in the first (A), second (B), and third (C) applications.

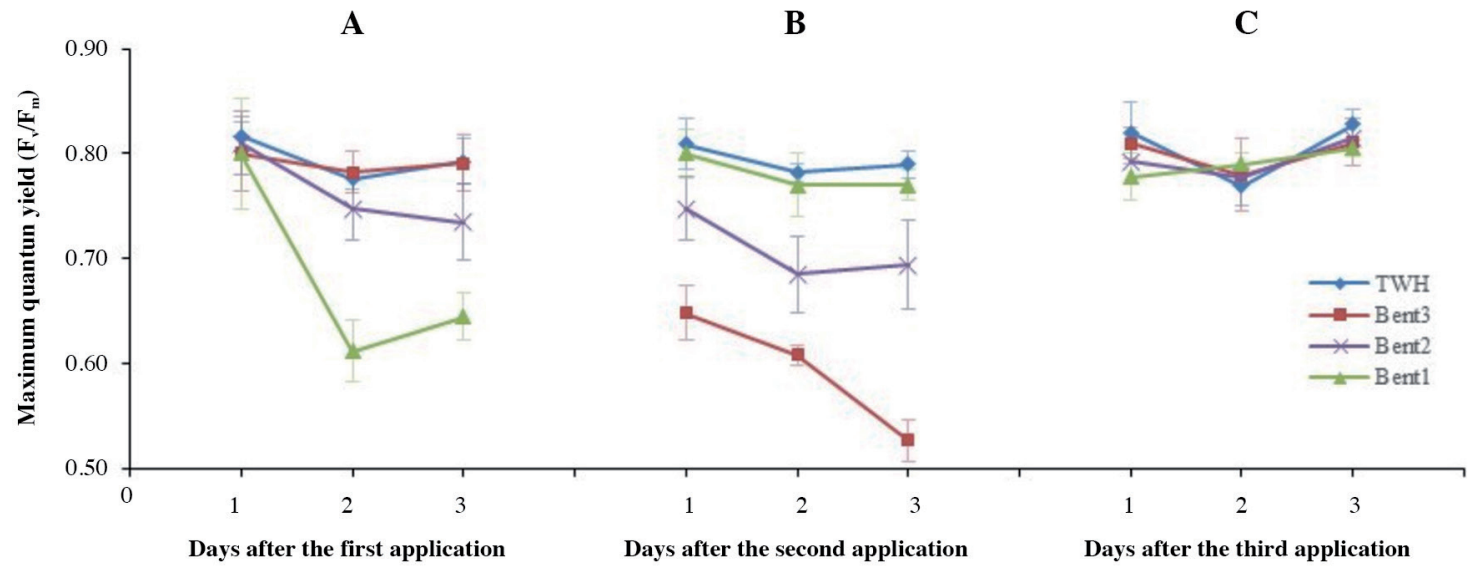

Bars represent the standard deviation of the mean in each treatment.

TWH: Treatment without herbicide application; Fom 1 and Bent1: full rate sprayed once; Fom2 and Bent2: split rate in two applications every $9 \mathrm{~d}$; Fom3 and Bent3: split rate in three applications every $9 \mathrm{~d}$.

in the bentazon treatments with three and two applications decreased to 0.61 and 0.69 , respectively. On the third day after the second application, only the $\mathrm{F}_{\mathrm{v}} / \mathrm{F}_{\mathrm{m}}$ value of the bentazon treatment with three applications continued to decrease to 0.53 , while the bentazon treatment with two applications remained at 0.69 .

Finally, for the third application (Figure 2C), $\mathrm{F}_{\mathrm{v}} / \mathrm{F}_{\mathrm{m}}$ values on the first, second, and third days were constant $(P>$ 0.05 ) and near 0.80 in all treatments. Under normal conditions, healthy superior plants have an optimum $F_{v} / F_{m}$ near 0.83 (Maxwell and Johnson, 2000); however, reported values in quinoa leaves range from 0.78 to 0.84 (Winkel et al., 2002).

For the fomesafen application, $F_{v} / F_{m}$ values were stable during the experiment, whereas $F_{v} / F_{m}$ values decreased and then recovered in the bentazon application, which indicates that the plant tolerated stress caused by the herbicide. The effect can be related to the mode of action of the herbicides; fomesafen specifically inhibits the protoporphyrinogen oxidase enzyme in chlorophyll biosynthesis and acts indirectly in photosynthesis. Bentazon is absorbed by the plant through the leaves, prevents protein D1 production, and slowly acts during several days in a direct way in PSII. Lootens and Vandecasteele (2000) conducted studies with similar crops and herbicides; they analyzed the effect of the herbicide diuron in a maize crop, measured chlorophyll fluorescence $4 \mathrm{~min}$ after it was applied on the adaxial side of the leaf, and this effect was heightened after $30 \mathrm{~min}$ with $\mathrm{F}_{\mathrm{v}} / \mathrm{F}_{\mathrm{m}}$ decreasing by approximately $40 \%$. This effect is possibly because phenylurea herbicides, such as linuron, diuron, or isoproturon, block the electron flow between the primary and secondary electron acceptors of PSII. Ali and Honermeier (2016) studied an artichoke crop and indicated that the damage to the photosynthetic apparatus was caused by the herbicides pyridate and phenmedipham because the greatest alterations in chlorophyll fluorescence were generated by these two herbicides.

\section{CONCLUSIONS}

Stress produced by the application of the herbicides fomesafen and bentazon in the absence of weeds affected quinoa crop yield; however, when splitting the rate into three sequential applications of both herbicides, once every $9 \mathrm{~d}$, it was sufficient to achieve a yield equal to the control without herbicide treatment. For both herbicides, the number of grains per plant was the variable that exhibited the greatest differences and directly affected yield in some treatments. Total polyphenol content was not altered by herbicide application despite affecting crop yield in some treatments. The herbicide fomesafen did not affect maximum quantum yield, whereas the herbicide bentazon affected it in each application. 


\section{ACKNOWLEDGEMENTS}

We wish to thank the Secretaría de Educación Superior, Ciencia, Tecnología e Innovación (SENESCYT, Ecuador) and the Instituto Nacional de Investigaciones Agropecuarias (INIAP, Ecuador) for providing the doctoral degree scholarship for Jorge Luis Merino Toro.

\section{REFERENCES}

Abderrahim, F., Huanatico, E., Segura, R., Arribas, S., Gonzalez, M., and Condezo-Hoyos, L. 2015. Physical features, phenolic compounds, betalains and total antioxidant capacity of coloured quinoa seeds (Chenopodium quinoa Willd.) from Peruvian Altiplano. Food Chemistry 183:83-90.

Ali, S., and Honermeier, B. 2016. Post emergence herbicides influence the leaf yield, chlorophyll fluorescence and phenolic compounds of artichoke (Cynara cardunculus L.) Scientia Horticulturae 203:216-223.

Baker, N., and Rosenqvist, E. 2004. Applications of chlorophyll fluorescence can improve crop production strategies: an examination of future possibilities. Journal of Experimental Botany 55:1607-1621.

Barbagallo, R., Oxborough, K., Pallet, K., and Baker, N. 2003. Rapid, non-invasive screening for perturbations of metabolism and plant growth using chlorophyll fluorescence imaging. Plant Physiology 132:485-493.

Bazile, D., Pulvento, C., Verniau, A., Al-Nusairi, M., Ba, D., and Breidy, J. 2016. Worldwide evaluations of quinoa: preliminary results from post international year of quinoa FAO projects in nine countries Frontiers in Plant Science 7:850.

Blokhina, O., Virolainen, E., and Fagerstedt, K.V. 2003. Antioxidants, oxidative damage and oxygen deprivation stress: a review. Annals of Botany 91:179-194.

Carciochi, R., Marique, G., and Dimitrov, K. 2014. Changes in phenolic composition and antioxidant activity during germination of quinoa seeds (Chenopodium quinoa Willd.) International Food Research Journal 21(2):676-773.

Das, S., and Mondal, T., 2014. Mode of action of herbicides and recent trends in development: a reappraisal. International Journal of Agricultural and Soil Science 2:27-32.

De Abreu, I., and Mazzafera, P. 2005. Effect of water and temperature stress on the content of active constituents of Hypericum brasilienne Choisy. Plant Physiology and Biochemistry 43:241-248.

Di Rienzo, J.A., Casanoves, F., Balzarini, M., Gonzalez, L., Tablada, M., y Robledo, C. 2017. InfoStat versión 2017. Grupo InfoStat, Facultad de Ciencias Agrarias, Universidad Nacional de Córdoba, Argentina.

Díaz, J., Seguel, I., y Morales, A. 2015. Quínoa: oportunidad y desafío para la agricultura familiar campesina en Chile. Revista Tierra Adentro. Especial Quínoa N¹08. p. 62-67.

Ekmekci, Y., and Terzioglu, S. 2005. Effects of oxidative stress induced by paraquat on wild and cultivated wheats. Pesticide Biochemistry and Physiology Journal 83:69-81.

Fischer, S., Wilckens, R., Jara, J., and Aranda, M. 2013. Variation in antioxidant capacity of quinoa (Chenopodium quinoa Will) subjected to drought stress. Industrial Crops and Products 46:341-349.

Hall, A. 1980. Los componentes fisiológicos del rendimiento de los cultivos. Revista Facultad de Agronomía 1(1):73-86.

Hess, F. 2000. Light-dependent herbicides: an overview. Weed Science 48:160-170.

Karimmojeni, H., Pirbaloti, A., Kudsk, P., Kanani, V., and Ghafori, A. 2013. Influence of postemergence herbicides on weed management in spring-sown linseed. Agronomy Journal 105:821-826.

Lascano, R., Melchiorre, N., Luna, M., and Trippi, S. 2003. Effect of photooxidative stress induced by paraquat in two wheat cultivars with differential tolerance to water stress. Plant Science 164:841-848.

Li, G., and Zhu, F. 2018. Quinoa starch: structure, properties, and applications. Carbohydrate Polymers 181:851-861.

Lootens, P., and Vandecasteele, P. 2000. A cheap chlorophyll a fluorescence imaging system. Photosynthetica 38:53-56.

Lukatkin, S., Gar'kova, N., Bochkarjova, S., Nushtaeva, V., and da Silva, J.A.T. 2013. Treatment with the herbicide TOPIK induces oxidative stress in cereal leaves. Pesticide Biochemistry and Physiology Journal 105:44-49.

Maxwell, K., and Johnson, G. 2000. Chlorophyll fluorescence- a practical guide. Journal of Experimental Botany 51:659-668.

Mehta, P., Jajoo, A., Mathur, S., and Bharti, S. 2010. Chlorophyll a fluorescence study revealing effects of high salt stress on Photosystem II in wheat leaves. Plant Physiology and Biochemistry 48:16-20.

Mellado, M., y Pedreros, A. 2005. Efecto de herbicidas aplicado durante la madurez del grano de trigo en el rendimiento y calidad del grano. Agricultura Técnica 65:312-318.

Merino, J., Pedreros, A., Fischer, S., and López, M.D. 2019. Critical period of weed interference on total polyphenol content in quinoa. Chilean Journal of Agricultural Research 79(3):405-414.

Miranda, M., Vega-Gálvez, A., López, L., Parada, G., Sanders, M., Aranda, M., et al. 2010. Impact of air-drying temperature on nutritional properties, total phenolic content and antioxidant capacity of quinoa seeds (Chenopodium quinoa Willd.) Industrial Crops and Products 32:258-263. 
Miranda, M., Vega-Gálvez, A., Martínez, E., López, J., Marín, R., Aranda, M., et al. 2013. Influence of contrasting environments on seed composition of two quinoa genotypes: nutritional and functional properties. Chilean Journal of Agricultural Research 73:108-116.

Molina, L., Pedreros, A., Matus, I., y Ruf, K. 2014. Control químico de malezas en quinoa (Chenopodium quinoa W.) Resúmenes del $65^{\circ}$ Congreso Anual de la Sociedad Agronómica de Chile. Simiente 84(1-4):1-182.

Mujica, A., y Canahua, A. 1989. Fases fenológicas del cultivo de la quinoa (Chenopodium quinoa Willd.) p. 23-27. In Curso taller, fenología de cultivos andinos y uso de la información agrometeorológica, Salcedo. 7-10 August. INIAA, EEZAILLPA, PICA, PISA, Puno, Perú.

Navruz-Varli, S., and Sanlier, N. 2016. Nutritional and health benefits of quinoa (Chenopodium quinoa Willd.) Journal of Cereal Science 69:371-376.

Olivoto, T., Nardino, M., Carvalho, I., Follmann, D., Szareski, V., Ferrari, M., et al. 2016. Plant secondary metabolites and its dynamical systems of induction in response to environmental factors: A review. African Journal of Agricultural Research 2(12):71-84.

Pavlovic, D., Vrbnicanin, S., Bozic, D., and Fischer A. 2008. Morphophysiological traits and atrazine sensitivity in Chenopodium album L. Pest Management Science 62:101-107.

Pedreros, A., y Tay, J. 2003. Efecto de aplicaciones secuenciales de herbicidas post emergentes para malezas de hoja ancha en poroto para grano seco. Resúmenes del 54 Congreso Anual de la Sociedad Agronómica de Chile. Simiente 73(3-4):15-61 .

Pitty, A. 2018. Modo de acción y resistencia de los herbicidas que interfieren en el fotosistema II de la fotosíntesis. Ceiba $55: 45-59$.

Rinella, M., Haferkamp, M., Masters, R., Muscha, J., Bellows, S., and Vermeire, L. 2010. Growth regulator herbicides prevent invasive annual grass seed production. Invasive Plant Science Management 3(1):12-16.

Winkel, T., Methy, M., and Thénot, F. 2002. Radiation use efficiency, chlorophyll fluorescence, and reflectance indices associated with ontogenic changes in water-limited Chenopodium quinoa leaves. Photosynthetica 40(2):227-232. 